\title{
Prevalence of hypovitaminosis $D$ in postmenopausal women: a systematic review
}

\author{
(D) Tania Valladares ${ }^{\mathbf{1 , 2}}$ \\ (iD) Ricardo Simões ${ }^{3}$ \\ (iD) Wanderley Bernardo ${ }^{4}$ \\ D Ana Carolina Basso Schmitt ${ }^{5}$ \\ (iD) Maria Regina A. Cardoso ${ }^{6}$ \\ (iD) José Mendes Aldrighi,
}

1. Women's Health Clinic, Barra Funda College Health Care Center, Santa Casa Sisters of Mercy Hospital of São Paulo, São Paulo, Brasil 2. University of São Paulo School of Public Health, São Paulo, Brasil 3. Department of Obstetrics and Gynecology, University of São Paulo School of Medicine Hospital das Clínicas, São Paulo, Brasil 4. Department of General Surgery, University of São Paulo School of Medicine, São Paulo, Brasil 5. Department of Physiotherapy, University of São Paulo School of Medicine, São Paulo, Brasil 6. Department of Epidemiology, University of São Paulo School of Medicine, São Paulo, Brasil 7. Department of Obstetrics and Gynecology, Santa Casa of São Paulo School of Medical Sciences, São Paulo, Brasil

http://dx.doi.org/10.1590/1806-9282.65.5.691

\section{SUMMARY}

BACKGROUND: Hypovitaminosis D is considered a global public health issue. Knowledge of its true dimensions will allow us to design interventions and plan preventive measures that can have a significant impact on human health.

OBJECTIVES: The aim of this study was to evaluate the prevalence of hypovitaminosis $D$, defined as a serum 25-hydroxyvitamin $D$ concentration $<30 \mathrm{ng} / \mathrm{ml}$, in postmenopausal women around the world, as well as to identify the potential associated factors.

METHODS: A systematic review was performed in accordance with the Preferred Reporting Items for Systematic Review and Meta-Analyses recommendations. Specific search terms were consulted in Medline, Excerpta Medica, and Latin-American and Caribbean Health Sciences Literature databases, with no restriction for the year or language of publication.

RESULTS: Of 451 studies initially identified, 32 were selected for analysis. Collectively, those 32 studies evaluated 21,236 postmenopausal women, of whom 16,440 (77.4\%) had serum 25 -hydroxyvitamin D concentrations $<30 \mathrm{ng} / \mathrm{ml}$. The reported prevalence of hypovitaminosis D ranged from 29\% (in the United States) to $99.4 \%$ (in China). In six of the studies, the prevalence was above $90 \%$.

CONCLUSIONS: If the criterion is the $30 \mathrm{ng} / \mathrm{ml}$ cut-off point, the majority of postmenopausal women in the world could be classified as having hypovitaminosis D. Among the studies evaluated, the lowest prevalence reported was nearly 30\%. Neither latitude, region of the world, nor laboratory methodology were found to be associated with the prevalence of hypovitaminosis $D$.

KEYWORDS: Vitamin D deficiency, Vitamin D, Postmenopause, Climacteric, Prevalence

\section{INTRODUCTION}

Vitamin D deficiency represents a major public health problem, not only because its prevalence is high (so high that it is considered a true epidemic) but also because of the considerable clinical repercussions $^{1-3}$. Its importance concerned to calcium homeostasis and bone metabolism are well known, but, following the identification of vitamin D recep- tors in various cells and organs of the body, including the pancreas, macrophages, endothelium, stomach, epidermis, colon, and placenta ${ }^{4}$, vitamin $\mathrm{D}$ has been shown to have major extra-skeletal (autocrine and paracrine) effects ${ }^{5}$. Vitamin D treatment has also been associated with reduced rate of falls ${ }^{6}$, mobility, worsening of muscle function, an increased risk 
of falls, and cognitive decline, as well as with an increased risk of Alzheimer's disease and depression'.

Vitamin D is naturally produced by the skin, and exposure to ultraviolet radiation is a key step in its synthesis ${ }^{7,8}$. Factors influencing that exposure, such as geographic location, cultural norms, skin color, use of sunscreen, and the modern lifestyle (more time spent indoors), can affect serum concentrations of 25-hydroxyvitamin D (25[OH]D).

Because human life expectancy has increased, many women live longer after menopause, when hypovitaminosis D can become more severe, not only because of the reduction in intestinal absorption due to the aging process but also because of the inherent hypoestrogenism in the postmenopausal period. In combination, these factors increase the risk of loss of bone mass ${ }^{9}$. From the above, it can be deduced that hypovitaminosis D can affect a large part of the population, and knowledge of its true population frequency can contribute to the formulation of public policies involving preventive measures and interventions ${ }^{10}$. Therefore, the objective of this systematic review was to evaluate the prevalence of hypovitaminosis D in postmenopausal women around the world.

\section{METHODS}

We conducted a search for cross-sectional studies that estimated the prevalence of hypovitaminosis D in postmenopausal women. We followed the recommendations established in the Preferred Reporting Items for Systematic Reviews and Meta-Analyses guidelines ${ }^{11}$, selecting studies in which the serum concentrations of 25(OH)D had been determined in postmenopausal women and, although measurements over the $20 \mathrm{ng} / \mathrm{mL}$ limit are considered normal by important entities ${ }^{12,13}$, the $30 \mathrm{ng} / \mathrm{ml}(75 \mathrm{nmol} / \mathrm{L})$ cut-off point had been used to distinguish between normality and insufficiency or deficiency because this is limit associated with the optimization of intestinal calcium absorption in postmenopausal wom$\mathrm{en}^{14}$. We excluded studies jointly evaluating women of reproductive age and postmenopausal women, studies that did not collect information regarding the menopausal status of the women, cohort studies of women with diseases, and case-control studies. When there was a control group comprising healthy postmenopausal women, data related to those women were included in the review, because the biochem- ical data from the controls were representative of the general population.

To identify eligible studies, we consulted the Medline, Latin-American and Caribbean Health Sciences Literature, and Excerpta Medica databases for entries up to September 2016, using the strategy outlined in Chart 1, without restricting the year of publication or language. The articles were selected through the process described in Figure 1. We also reviewed the publications listed in the bibliographies of the articles selected. The selection, evaluation of the titles, and evaluation of the abstracts of the studies identified in the databases consulted were conducted by two investigators with experience in conducting systematic reviews. The investigators worked independently, strictly adhering to the inclusion and exclusion criteria. To extract data of interest for this review, the investigators then evaluated the remaining articles for information regarding the measurement of serum 25(OH)D concentrations; study locale; participant ages and menopausal status; sample size and selection criteria; and the methods used in the clinical and biochemical analyses. When there was disagreement between the investigators regarding the selection of studies, a third investigator was consulted. The data were compiled into a Microsoft Office Excel spreadsheet. The primary endpoint of interest was the prevalence of hypovitaminosis $\mathrm{D}$, the reference range for serum $25(\mathrm{OH}) \mathrm{D}$ concentrations being $\geq 30 \mathrm{ng} / \mathrm{ml}$.

\section{RESULTS}

Of a total of 448 articles initially identified, 32 were selected for inclusion in the final analysis (Figure 1). One study was excluded because it presented conflicting results between the prevalence of hypovitaminosis $\mathrm{D}$ and the maximum serum concentration of 25(OH)D reported. Most of the studies selected were cross-sectional cohort studies that employed the baseline measures required for inclusion in this review, although a few were case-control studies in

\section{CHART 1 SEARCH STRATEGIES, PER DATABASE}

\begin{tabular}{l|l} 
Database & Strategy \\
\hline Medline/PubMed & $\begin{array}{l}\text { "postmenopause"[All Fields] AND } \\
\text { "vitamin d deficiency"[All Fields] }\end{array}$ \\
\hline $\begin{array}{l}\text { Latin-American and Caribbe- } \\
\text { an Health Sciences Literature }\end{array}$ & $\begin{array}{l}\text { postmenopause [words] AND } \\
\text { vitamin d deficiency [words] }\end{array}$ \\
\hline Excerpta Medica & "vitamin d deficiency" AND "post- \\
menopause" AND "prevalence"
\end{tabular}


TABLE 1. STUDIES SELECTED

\begin{tabular}{|c|c|c|c|c|c|c|c|}
\hline \multirow[t]{2}{*}{$\begin{array}{l}\text { Author and year of publi- } \\
\text { cation }\end{array}$} & $\begin{array}{l}\text { Mean age, } \\
\text { years }\end{array}$ & Women & $\begin{array}{l}\text { Women with } \\
\text { HD }\end{array}$ & $\begin{array}{l}25(\mathrm{OH}) \mathrm{D} \\
\mathrm{ng} / \mathrm{ml}\end{array}$ & \multirow[t]{2}{*}{ Latitude } & \multirow[t]{2}{*}{$\operatorname{VDS}(\%)$} & \multirow[t]{2}{*}{ Locale } \\
\hline & Mean (SD) & $N$ & $n(\%)$ & Mean $^{*}$ & & & \\
\hline El Maataoui et al., $2016^{32}$ & $59(8.2)$ & 186 & $144(77.4)$ & 20.1 & $32^{\circ} \mathrm{N}$ & no & Morocco \\
\hline Andreozzi et al., $2015^{37}$ & $64.4(8.4)$ & 62 & $48(77.4)$ & ND & $41.87^{\circ} \mathrm{N}$ & no & Italy \\
\hline Alipour et al., $2014^{33}$ & ND & 140 & $113(80.7)$ & ND & $35.7^{\circ} \mathrm{N}$ & no & Iran \\
\hline Godala et al., $2014^{26}$ & $55.4(3.5)$ & 36 & $30(83.3)$ & $\begin{array}{l}23.52(13.39- \\
45.87)\end{array}$ & $51.76^{\circ} \mathrm{N}$ & no & Poland \\
\hline Cheng et al., $2014^{17}$ & ND & 3345 & $2727(81.5)$ & ND & $25-40^{\circ} \mathrm{N}$ & 47.8 & $\begin{array}{l}\text { USA ( } 40 \text { clinical } \\
\text { facilities) }\end{array}$ \\
\hline Aloia et al., $2014{ }^{18}$ & $58.8(4.9)$ & 76 & $59(78.0)$ & 25.2 & $40.44^{\circ} \mathrm{N}$ & no & USA (Mineola, NY) \\
\hline $\begin{array}{l}\text { Gómez-de-Tejada Romero et } \\
\text { al., } 20144^{34}\end{array}$ & $54.8(11.8)$ & 1221 & $892(73.0)$ & 24.3 & $28.12^{\circ} \mathrm{N}$ & ND & $\begin{array}{l}\text { Spain (Canary } \\
\text { Islands) }\end{array}$ \\
\hline Hoon et al., $2014^{19^{\star \star *}}$ & ND & 605 & 509 (84.2) & ND & $37.56^{\circ} \mathrm{N}$ & no & Korea \\
\hline Klisic et al., $2014^{35 \star \star}$ & ND & 188 & $151(80.3)$ & ND & $42.44^{\circ} \mathrm{N}$ & ND & Montenegro \\
\hline Stolarczyk et al., $2014^{\mathbf{2 7}}$ & $70.8(7.6)$ & 107 & $95(88.8)$ & 19.55 & $52.26^{\circ} \mathrm{N}$ & no & Poland \\
\hline Mata-Granados et al., $2013^{38}$ & $5 . .4(6.4)$ & 232 & $217(93.7)$ & 17.5 & $37.5^{\circ} \mathrm{N}$ & no & $\begin{array}{l}\text { Spain (Junta de } \\
\text { Andalucía) }\end{array}$ \\
\hline Asadi et al., $2013^{28}$ & $52.7(5.0)$ & 110 & $77(70.0)$ & 19.28 & $35.7^{\circ} \mathrm{N}$ & no & Iran \\
\hline Casado-Díaz et al., $2013{ }^{42}$ & $57.4(12.8)$ & 229 & $190(83.0)$ & 21.76 & $37.8^{\circ} \mathrm{N}$ & no & Spain (Cordoba) \\
\hline $\begin{array}{l}\text { Hacker-Thompson et al., } \\
2012{ }^{15}\end{array}$ & $63.9(7.8)$ & 122 & $36(29.5)$ & ND & $41^{\circ} \mathrm{N}$ & 82.0 & $\begin{array}{l}\text { USA (San Francisco, } \\
\text { CA) }\end{array}$ \\
\hline Hussein et al., $2012^{43 \star \star}$ & ND & 223 & $212(95.0)$ & ND & $21.29^{\circ} \mathrm{N}$ & ND & Saudi Arabia \\
\hline El Maghraoui et al., $2012^{36}$ & $58.8(8.2)$ & 178 & $152(85.3)$ & $\begin{array}{l}15.8 \\
(3.0-49.1) \\
\end{array}$ & $34^{\circ} \mathrm{N}$ & no & Morocco \\
\hline Rudenka et al., $2012^{29 * \star}$ & $63(7.8)$ & 205 & $189(92.0)$ & ND & $53.9^{\circ} \mathrm{N}$ & 62.1 & Belarus \\
\hline Baro; $2011^{44 \star \star}$ & ND & 150 & $119(79.3)$ & ND & $41.38^{\circ} \mathrm{N}$ & ND & Spain (Barcelona) \\
\hline Harinarayan et al., $2011^{20}$ & $53(0.2)$ & 136 & $124(89.7)$ & ND & $13.40^{\circ} \mathrm{N}$ & no & India \\
\hline Sternberg et al., $2011^{21 \star \star}$ & 61.4 & 112 & $65(57.9)$ & ND & $35^{\circ} \mathrm{S}$ & ND & Argentina \\
\hline Zhao et al., $2011^{16}$ & $64.1(9.2)$ & 1724 & $1714(99.4)$ & $\begin{array}{l}13.2 \\
(4.0-35.6) \\
\end{array}$ & $39.54^{\circ} \mathrm{N}$ & no & China \\
\hline $\begin{array}{l}\text { Laktasic-Zerjavic et al., } 2010 \\
\text { 39 }\end{array}$ & $61.2(8.8)$ & 120 & $111(92.5)$ & $\begin{array}{l}46.94 \\
(10-110.9)\end{array}$ & $42-46^{\circ}$ & no & Croatia \\
\hline Allali et al., $2009^{30}$ & $55.9(6.8)$ & 307 & $282(92.0)$ & 17.7 & $33.97^{\circ} \mathrm{N}$ & no & Morocco \\
\hline Bobinac et al., $2009^{45^{\star *}}$ & ND & 720 & $455(63.3)$ & 27.33 & $45.32^{\circ} \mathrm{N}$ & ND & Croatia \\
\hline Maddah et al., 200940 & $63.4(8.7)$ & 646 & $536(83.0)$ & 19.99 & $37.12^{\circ} \mathrm{N}$ & ND & Iran \\
\hline Poiana et al., $2009^{46 * \star}$ & 58.4 & 174 & $144(82.8)$ & ND & $44.43^{\circ} \mathrm{N}$ & ND & Romania \\
\hline Stewart et al., $2009^{22}$ & $54.3(3.3)$ & 242 & $153(63.3)$ & ND & $\begin{array}{l}41.8^{\circ} \mathrm{N} \text { and } \\
38.6^{\circ} \mathrm{N}\end{array}$ & 53.7 & $\begin{array}{l}\text { USA (Ames, IA and } \\
\text { Davis, CA) }\end{array}$ \\
\hline Lee et al., $2009^{23}$ & $58(8)$ & 254 & $112(44.0)$ & 33.3 & $37.56^{\circ} \mathrm{N}$ & 35.8 & Korea \\
\hline Al-Turki et al., $2008^{24}$ & $56.1(4.9)$ & 200 & $110(55.0)$ & ND & $26.22^{\circ} \mathrm{N}$ & no & Saudi Arabia \\
\hline Manicourt et al., $2008^{31}$ & $65(8)$ & 85 & $53(62.0)$ & 25.6 & $50.85^{\circ} \mathrm{N}$ & no & Belgium \\
\hline Bruyère et al., $2007^{25}$ & $74.2(7.1)$ & 8532 & $6186(72.7)$ & 24.04 & $\begin{array}{l}40.46- \\
55.17^{\circ} \mathrm{N}\end{array}$ & 24 & $\begin{array}{l}\text { Belgium, France, } \\
\text { Spain, Germany, } \\
\text { Hungary, Italy, Po- } \\
\text { land, and the United } \\
\text { Kingdom }\end{array}$ \\
\hline Garnero et al., 200741 & $62.2(8.8)$ & 669 & $490(73.2)$ & ND & $45.76^{\circ} \mathrm{N}$ & ND & France \\
\hline
\end{tabular}

HD, hypovitaminosis D; VDS, Vitamin D supplementation; ND, no data. ${ }^{\star}$ Plus minimum and maximum values, where provided. ${ }^{\star}$ Published in poster form.

which the control group was representative of the population of interest. We also included eight poster publications that presented the necessary minimum information (Table 1).
Table 1 shows the information obtained from the selected studies ${ }^{15-46}$ : the names of the authors and year of publication; the mean ages of the participants; the number of women evaluated; the number 


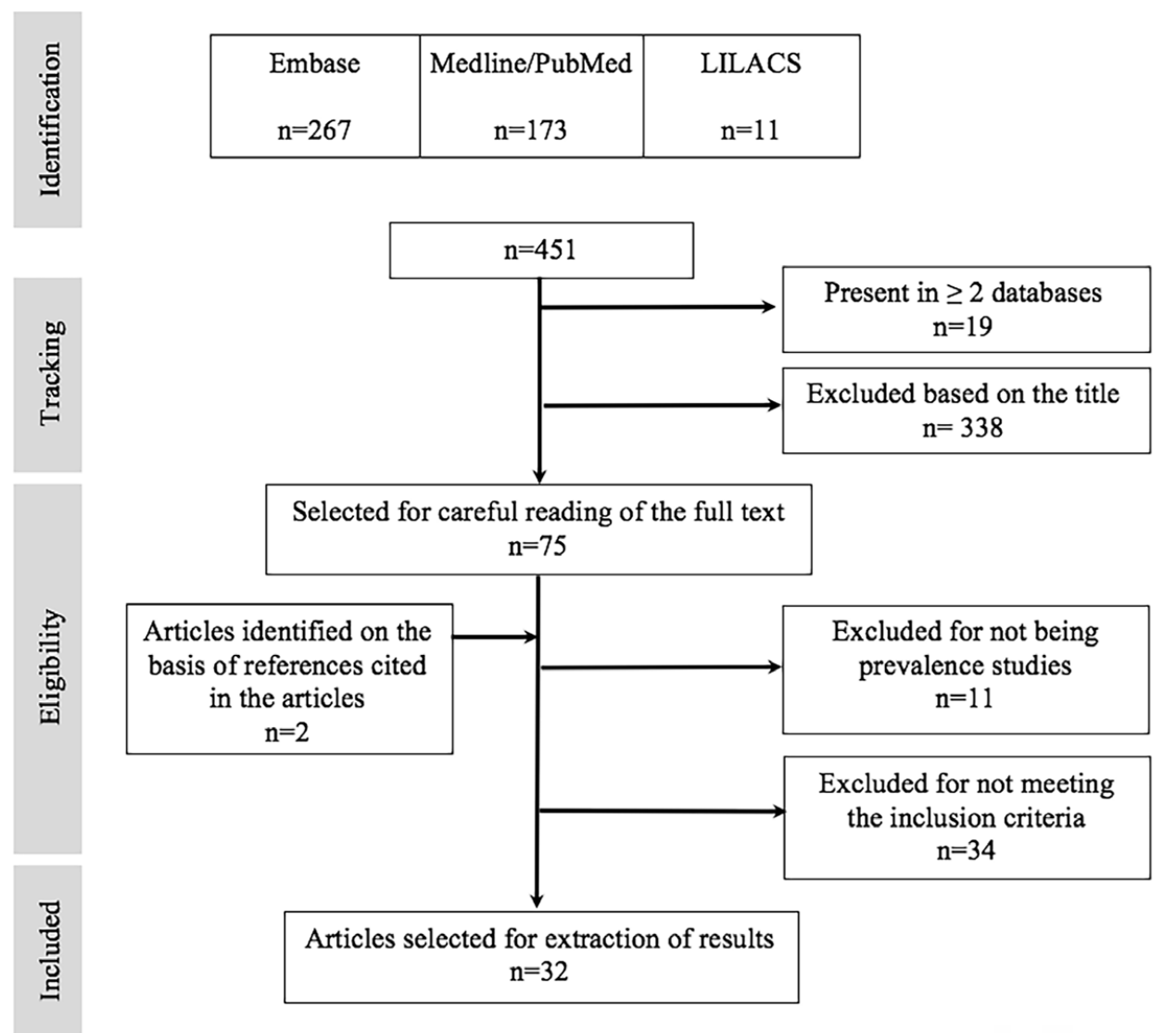

Embase, Excerpta Medica database; LILACS, Literatura Latinoamericana y del Caribe en Ciencias de la Salud (Latin-American and Caribbean Health Sciences Literature).

of subjects with serum 25(OH)D concentrations < $30 \mathrm{ng} / \mathrm{ml}$; the prevalence of hypovitaminosis $\mathrm{D}$; the mean 25(OH)D concentrations, with minimum and maximum values when available; and the latitude and locale of the study. Collectively, the selected studies evaluated 21,236 women, 16,440 (77.4\%) of whom had serum 25(OH)D concentrations $<30 \mathrm{ng} /$ $\mathrm{ml}$. Sample sizes ranged from 36 to 8,532 , the prevalence of hypovitaminosis D ranging from 29.5\% (in San Francisco, CA) [15] to $99.4 \%$ (in Beijing, China) ${ }^{12}$. The laboratory techniques used were radioimmunoassay, in nine studies ${ }^{17-25}$; chemiluminescent immunoassay, in $\operatorname{six}^{26-31}$; electrochemiluminescence, in six ${ }^{16,32-36}$; high-performance liquid chromatography (HPLC), in three ${ }^{15,37,38}$, ELISA, in two ${ }^{39,40}$, and competitive protein-binding techniques, in one ${ }^{41}$. In five studies, the laboratory technique employed was not reported ${ }^{42-46}$.

In six of the 32 studies, the prevalence of hypovitaminosis D was above $90 \% 16,29,30,38,39,43$. In the study conducted in Beijing ${ }^{16}$, only 10 of the 1,724 women evaluated had serum concentrations of 25(OH)D above $30 \mathrm{ng} / \mathrm{ml}$. The prevalence of hypovitaminosis D was above $90 \%$ in seven other cities around the world: $95.0 \%$ in Jeddah, Saudi Arabia ${ }^{43}$; 93.7\% in Junta de Andalucía, Spain ${ }^{38}$; $92.5 \%$ in Zagreb, Croatia ${ }^{39}$; 92.0\% in Minsk, Belarus ${ }^{29}$; and $92.0 \%$ in Rabat, Morocco $^{32}$. Even at the sites where the prevalence of hypovitaminosis D was lowest, it was relatively high: approximately $30 \%$ in San Francisco, $\mathrm{CA}^{15} ; 44.0 \%$ in (one of the studies conducted in) South Korea ${ }^{23}$, and 55.0\% in Saudi Arabia ${ }^{24}$.

Stratifying the results by continent, we found that the prevalence of hypovitaminosis D in North America, Europe, Africa, the Middle East, and Asia was $78.6 \%, 73.6 \%, 86,1 \% 81.5 \%$, and $90.4 \%$, respectively. The fact that the prevalence was highest in Asia was due to the study conducted in Beijing, which involved 1,724 women, almost all of whom had hypovitaminosis $\mathrm{D}^{16}$. With the search strategy adopted, only one study from South America was selected, a study conducted in Argentina and involving 112 women, in 
which the estimated prevalence of hypovitaminosis D was $57.9 \%{ }^{21}$.

Multiple studies carried out in a single country presented very different results. In a study conducted in South Korea in 2009 and involving 254 women $^{23}$, the prevalence of hypovitaminosis D was $44.0 \%$, compared with $84.2 \%$ in another, more recent study involving 605 women evaluated in that same country ${ }^{19}$. In the studies conducted in the United States, the reported prevalence ranged from $29.5 \%{ }^{15}$ to $81.5 \%{ }^{17}$. In two studies conducted in Saudi Arabia, one in the city of Al Khobar in $2008^{24}$ and the other in the city of Jeddah in $2012^{43}$, the reported prevalence was $55.0 \%$ and $95.0 \%$, respectively.

Although comparisons were made among latitudes and continents, we identified no factors that could explain the differences observed. The reported prevalence of hypovitaminosis D was high even in populations in which the rate of vitamin $\mathrm{D}$ supplementation was near $50 \%{ }^{19}$, or even above $60 \%{ }^{29}$, although it was lower in the studies in which women receiving vitamin D supplementation were exclud$\mathrm{ed}^{24}$. We identified no association between the prevalence of hypovitaminosis D and the laboratory techniques employed.

\section{DISCUSSION}

One of the most important aspects of this review is the fact that, to our knowledge, this is the first study to show the worldwide distribution of the prevalence of hypovitaminosis D according to the laboratory technique employed, specific geographic location, and latitude. Another important aspect was the selection of studies involving healthy postmenopausal women, with the objective of avoiding biases caused by treatments or diseases concerning the serum concentrations of $25(\mathrm{OH}) \mathrm{D}$. We chose to include studies in which a portion of the population was using vitamin D supplementation, as long as the samples were representative of the local population of healthy postmenopausal women.

In this review, we did not find the prevalence of hypovitaminosis $\mathrm{D}$ to be associated with geographic location, latitude, use of vitamin D supplementation, or the laboratory technique employed. We identified considerable variation among studies conducted in the same country, in terms of the prevalence of hypovitaminosis D. Between the two studies conducted in South Korea, the one conducted in $2009^{23}$, in which the prevalence of hypovitaminosis D was $44.0 \%$, included women under treatment for osteoporosis or menopause, which could account for the difference in relation to the 2014 study $^{19}$, which involved only women not receiving such treatment and in which the prevalence was $84.2 \%$. It is of note that both of those studies were conducted in the city of Seoul. For the 2009 study $^{23}$, if only the women not receiving vitamin D supplementation $(\mathrm{n}=91)$ were evaluated, the prevalence would be $56 \%$. In addition, the women evaluated by those authors were under treatment at a referral center for hormone replacement therapy or osteoporosis. Those treatments could have generated behavioral changes that had a positive influence on serum concentrations of 25(OH)D (engaging in outdoor activities, increased exposure to the sun, and consumption of foods rich in vitamin D). Similarly, in the United States, the prevalence of hypovitaminosis D ranged from as high as $81.5 \%$, in a multicenter study $^{17}$, to as low as $29.5 \%$, in the study conducted in San Francisco ${ }^{15}$. Those two studies, however, were quite different. The first was an assessment of baseline serum 25(OH)D concentrations measured at the start of the follow-up of the Women's Health Initiative Observational Study, involving a total of 3,345 postmenopausal women followed at 40 clinical institutions throughout the United States, where approximately $50 \%$ of the participants were receiving vitamin D supplementation. The second study, conducted by Hacker-Thompson et al. ${ }^{15}$, involved a much smaller sample, comprising 122 participants, $82 \%$ of whom were receiving vitamin D supplementation. In addition, the laboratory technique used in both studies was HPLC, a technique described as being highly sensitive $^{1,4}$. In Saudi Arabia, blood samples were collected between January and May 2008 in the study conducted in the city of $\mathrm{Al} \mathrm{Khobar}{ }^{24}$, whereas they were collected throughout 2011 in the study conducted in the city of Jeddah ${ }^{43}$. However, the latter study provided no information on the laboratory technique used.

The countries of Europe were represented in 15 studies, the largest of which involved more than 8,500 postmenopausal women in nine countries ${ }^{25}$. In that study, serum 25(OH)D concentrations were determined by radioimmunoassay, although all of the laboratory techniques described in this review were used in at least one of the studies conducted in Europe. The prevalence of hypovitaminosis $\mathrm{D}$ was the lowest $(62.0 \%)$ in Belgium and the highest $(92.5 \%)$ in 
Spain. The high prevalence in the study conducted in Spain was not explained by geographic location or laboratory technique, and the most sensitive technique, HPLC, was used in that study. Morocco, the only African country represented in this review, accounted for three of the studies evaluated ${ }^{30,32,36}$, among which the prevalence ranged from $77.4 \%$, in a study using electrochemiluminescence and collecting samples between November 2008 and October $2009^{32}$, to $92.0 \%$, in a study using chemiluminescent immunoassay and collecting samples between June and August of an unspecified year ${ }^{30}$. These data did little to explain the difference found, given that the prevalence was higher in the study conducted only during the months of maximum solar radiation in that country ${ }^{30}$. Five of the studies selected had been conducted in the Middle East, three in Iran ${ }^{28,33,40}$ and two in Saudi Arabia ${ }^{24,43}$. The lowest and highest values for the prevalence of hypovitaminosis D in the Middle East (55.0\% and 95.0\%, respectively) were both reported in studies conducted in Saudi Arabia ${ }^{24,43}$. Researchers working in countries where Islam is the predominant religion often cite cultural and clothing issues as major factors inhibiting the endogenous production of vitamin D. In this review, we found that the mean prevalence of hypovitaminosis D in the Middle East was 78.6\%, lower than that found in North America (81.4\%), where the culture is very different from that of Muslim countries and the clothing designed for women does not necessarily cover their entire bodies. Therefore, we can't assume that the low serum concentrations of 25(OH)D reported for Muslim countries correlate with the type of clothing used.

Studies about hypovitaminosis D in postmenopausal women brings knowledge about a factor strongly associated with osteoporosis, which is particularly prevalent in this group. The knowledge about other population groups, such as premenopausal women, however, is desirable to allow comparisons that improve the understanding of hypovitaminosis D and its possible triggers.

This review has some limitations. The lack of standardization of the laboratory technique employed in the measurement of serum $25(\mathrm{OH}) \mathrm{D}$ concentrations and the different times of year during which the blood samples were collected made it difficult to compare the results across studies. Also, some studies with large sample sizes had to be excluded, some because they evaluated women with diseases such as osteopenia or osteoporosis and others because they did not present serum 25(OH)D concentrations with a cut-off point of $30 \mathrm{ng} / \mathrm{ml}$. Furthermore, in some countries, a large part of the postmenopausal population use vitamin D supplementation, which creates a situation in which the potential vitamin D status of those populations could be masked. Nevertheless, we believe that this review has achieved its primary goals, showing the available information on the prevalence of hypovitaminosis $D$ in postmenopausal women around the world and providing a global perspective on the problem.

\section{CONCLUSION}

The analysis of the selected studies revealed that the prevalence of hypovitaminosis D is high among postmenopausal women, affecting a large part of the population, even in the regions where that prevalence is lowest. Given the importance of vitamin D in women's health, further studies are needed in order to determine the actual impact of this finding.

\section{RESUMO}

INTRODUção: A hipovitaminose D é considerada um problema de saúde pública global. O conhecimento de suas verdadeiras dimensões nos permitirá projetar intervenções e planejar medidas preventivas que possam ter um impacto significativo na saúde humana.

OBJETIVO: O objetivo deste estudo foi avaliar a prevalência de hipovitaminose D, definida como concentração sérica de 25-hidroxivitamina $D<30 \mathrm{ng} / \mathrm{ml}$, em mulheres na pós-menopausa em todo o mundo, bem como identificar os potenciais fatores associados.

MÉTODOS: Uma revisão sistemática foi realizada de acordo com as recomendações de Itens de Relatórios Preferenciais para Revisão Sistemática e Meta-Análises. Os termos de pesquisa específicos foram consultados nas bases de dados Medline, Excerpta Medica e Literatura Latino-Americana e do Caribe em Ciências da Saúde, sem restrição para o ano ou idioma de publicação.

RESULTADOS: Dos 451 estudos inicialmente identificados, 32 foram selecionados para análise. Coletivamente, esses 32 estudos avaliaram 21.236 mulheres na pós-menopausa, das quais 16.440 (77,4\%) apresentavam concentrações séricas de 25-hidroxivitamina D <30 $\mathrm{ng} / \mathrm{ml}$. A prevalência relatada de hipovitaminose D variou de 29\% (nos Estados Unidos) a 99,4\% (na China). Em seis dos estudos, a prevalência foi superior a $90 \%$.

CONCLUSÕES: Se o critério é o ponto de corte de $30 \mathrm{ng} / \mathrm{ml}$, a maioria das mulheres na pós-menopausa no mundo poderia ser classificada como tendo hipovitaminose D. Entre os estudos avaliados, a menor prevalência relatada foi de quase 30\%. Nem latitude, região do mundo, nem metodologia laboratorial foram encontrados para ser associados com a prevalência de hipovitaminose D. 


\section{REFERENCES}

1. Maeda SS, Borba VZ, Camargo MB, et al. Brazilian Society of Endocrinology and Metabology (SBEM). Recommendations of the Brazilian Society of Endocrinology and Metabology (SBEM) for the diagnosis and treatment of hypovitaminosis D. Arq Bras Endocrinol Metabol. 2014;58(5):411-33.

2. Holick MF, Binkley NC, Bischoff-Ferrari HA, et al. Evaluation, treatment, prevention of vitamin D deficiency: an Endocrine Society clinical practice guideline. | Clin Endocrinol Metab. 2011;96:1911-1930

3. IOM (Institute of Medicine) 2011 Dietary reference intakes for calcium and vitamin D. Committee to Review Dietary Reference Intakes for Calcium and Vitamin D. Washington, DC: National Academies Press, Institute of Medicine.

4. Thacher TD, Clarke BL. Vitamin D insufficiency. Mayo Clin Proc. 2011;86:50-60

5. Al Nozha OM. Vitamin D and extra-skeletal health: causality or consequence. Int J Health Sci (Qassim). 2016;10(3):443-52.

6. Gallagher $\mathrm{JC}$. The effects of calcitriol on falls and fractures and physical performance tests. J Steroid Biochem Mol Biol. 2004;89- 90(1-5):497-501

7. Holick MF, Chen TC, Lu Z, Sauter E. Vitamin D and skin physiology: a D-lightful story. I Bone Miner Res. 2007;22(Suppl 2):V28-V33.

8. Bandeira F, Griz L, Dreyer P, Eufrazino C, Bandeira C, Freese E. Vitamin D deficiency: a global perspective. Arq Bras Endocrinol Metab. 2006;50(4):640-646.

9. Pérez-López FR, Brincat M, Erel CT, et al. EMAS position statement: Vitamin D and postmenopausal health. Maturitas. 2012;71(1):83-8.

10. Baccaro LF, Conde DM, Costa-Paiva L, Pinto-Neto AM. The epidemiology and management of postmenopausal osteoporosis: a viewpoint from Brazil. Clin Interv Aging. 2015;10:583-91.

11. Moher D, Liberati A, Tetzlaff J, Altman DG; PRISMA Group. Preferred reporting items for systematic reviews and meta-analyses: the PRISMA statement. BMJ. 2009;339:b2535.

12. Ferreira CES, Maeda SS, Batista MC, Lazaretti-Castro M, Vasconcellos LS, Madeira $M$, et al. Consensus - reference ranges of vitamin D $[25(\mathrm{OH}) \mathrm{D}]$ from the Brazilian medical societies. Brazilian Society of Clinical Pathology/Laboratory Medicine (SBPC/ML) and Brazilian Society of Endocrinology and Metabolism (SBEM). J Bras Patol Med Lab 2017;53(6):377-381.

13. Munns CF, Shaw N, Kiely M, Specker BL, Thacher TD, Ozono K, Michigami T, Tiosano D, Mughal MZ, Mäkitie O, Ramos-Abad L, Ward L, DiMeglio LA, Atapattu N, Cassinelli H, Braegger C, Pettifor JM, Seth A, Idris HW, Bhatia V, Fu J, Goldberg G, Sävendahl L, Khadgawat R, Pludowski P, Maddock |, Hyppönen E, Oduwole A, Frew E, Aguiar M, Tulchinsky T, Butler G, Högler W. Global Consensus Recommendations on Prevention and Management of Nutritional Rickets. J Clin Endocrinol Metab. 2016;101(2):394415.

14. Heaney RP, Dowell MS, Hale CA, Bendich A. Calcium absorption varies within the reference range for serum 25-hydroxyvitamin D. I Am Coll Nutr. 2003; 22:142-6.

15. Hacker-Thompson A, Schloetter M, Sellmeyer DE. Validation of a dietary vitamin $D$ questionnaire using multiple diet records and the block 98 health habits and history questionnaire in healthy postmenopausal women in northern California. J Nutr. 2012;142(9):1705-12.

16. Zhao I, Xia W, Nie M, et al. The levels of bone turnover markers in Chinese postmenopausal women: Peking Vertebral Fracture study. Menopause. 2011;18(11):1237-43.

17. Cheng TY, Millen AE, Wactawski-Wende J, et al. Vitamin D intake determines vitamin d status of postmenopausal women, particularly those with limited sun exposure. J Nutr. 2014;144(5):681-9.

18. Aloia JF, Dhaliwal $R$, Shieh $A$, et al. Vitamin $D$ supplementation increases calcium absorption without a threshold effect. Am J Clin Nutr. 2014;99(3):624-31.

19. Hoon K, Ku S, Suh C, Kim S, Choi Y, Kim I. The relationship between serum level of vitamin $d$ and metabolic syndrome in Korean postmenopausal women: A population-based study. Abstracts of Posters, Climacteric. 2014;17(1):48-108

20. Harinarayan CV, Sachan A, Amaresh RP, Satish KM, Prasad UV, Srivani P. Vitamin D status and bone mineral density in women of reproductive and postmenopausal age groups: A cross-sectional study from south India. J Assoc Phys India. 2011;59(11):698-704.
21. Sternberg KG, Salmun D, Yankelevich D, Moggia MS, Provenzano S. Serum vitamin $\mathrm{D}$ levels determination in postmenopausal women. Abstracts of Posters, Climacteric. 2011;14(1):191-2.

22. Stewart JW, Alekel DL, Ritland LM, Van Loan M, Gertz E, Genschel U. Serum 25-hydroxyvitamin $D$ is related to indicators of overall physical fitness in healthy postmenopausal women. Menopause. 2009;16(6):1093-101.

23. Lee ES, Ahn |, Park HM. Serum vitamin D status of Korean postmenopausal women during the winter months. Asia Pac J Clin Nutr. 2009;18(1):2933.

24. Al-Turki HA, Sadat-Ali M, Al-Elq AH, Al-Mulhim FA, Al-Ali AK. 25-Hydoxyvitamin D levels among healthy Saudi Arabian women. Saudi Med J. 2008;29(12):1765-8.

25. Bruyère $O$, Malaise $O$, Neuprez A, Collette J, Reginster JY. Prevalence of vitamin D inadequacy in European postmenopausal women. Curr Med Res Opin. 2007;23(8):1939-44.

26. Godala M, Materek-Kuśmierkiewicz I, Moczulski D, et al. Assessment of $25(\mathrm{OH}) \mathrm{D}$ vitamin concentration in plasma of residents of Lodz with metabolic syndrome in pre and postmenopausal period. Prz Menopauzalny. 2014;13(5):293-7.

27. Stolarczyk A, Horvath A, Szczechura M, Kaminska M, Dziechciarz P. High prevalence of vitamin D insufficiency in community-dwelling postmenopausal Polish women. Prz Menopauzalny. 2014;13(5):289-92.

28. Asadi M, Jouyandeh Z, Nayebzadeh F, Qorbani M. Does aging increase vitamin D serum level in healthy postmenopausal women? Acta Med Iran. 2013;51(10):701-4.

29. Rudenka E, Samokhovec V, Vasilenka E, Adamenka A, Rudenka A. Determination of vitamin d status of postmenopausal women living in Belarus. Osteoporos Int. 2012;23 (7):794-5.

30. Allali F, El Aichaoui S, Khazani H, et al. High Prevalence of Hypovitaminosis D in Morocco: Relationship to Lifestyle, Physical Performance, Bone Markers, and Bone Mineral Density. Semin Arthritis Rheum. 2009;38(6):444-51.

31. Manicourt DH, Devogelaer JP. Urban tropospheric ozone increases the prevalence of vitamin D deficiency among Belgian postmenopausal women with outdoor activities during summer. J Clin Endocrinol Metab. 2008;93(10):3893-9.

32. El Maataoui A, Biaz A, El Machtani S, et al. Vitamin D status in healthy Moroccan men and women aged 50 years and older: a cross-sectional study. Arch Osteoporos. 2016;11(1):24

33. Alipour S, Saberi A, Seifollahi A, Shirzad N, Hosseini L. Risk factors and prevalence of vitamin d deficiency among Iranian women attending two university hospitals. Iran Red Crescent Med J. 2014;16(10):e15461.

34. Gómez-de-Tejada Romero MJ, Navarro Rodríguez MD, Saavedra Santana P, Quesada Gómez JM, Jódar Gimeno E, Sosa Henríquez M. Prevalence of osteoporosis, vertebral fractures and hypovitaminosis D in postmenopausal women living in a rural environment. Maturitas. 2014;77(3):282-6.

35. Klisic A, Perunicic V, Antunovic T, Soldatovic I, Jovanovic M, Kavaric N. The prevalence of vitamin D deficiency among postmenopausal women in Montenegro. Clin Chem Lab Med. 2014;52(1):1742.

36. El Maghraoui A, Ouzzif Z, Mounach A, et al. Hypovitaminosis D and prevalent asymptomatic vertebral fractures in Moroccan postmenopausal women. BMC Womens Health. 2012;12:11.

37. Andreozzi P, Verrusio W, Viscogliosi G, et al. Relationship between vitamin $D$ and body fat distribution evaluated by DXA in postmenopausal women. Nutrition. 2016;32(6):687-92.

38. Mata-Granados JM, Cuenca-Acevedo JR, Luque de Castro MD, Holick MF, Quesada-Gómez JM. Vitamin D insufficiency together with high serum levels of vitamin A increases the risk for osteoporosis in postmenopausal women. Arch Osteoporos. 2013;8:124.

39. Laktasic-Zerjavic N, Korsic M, Crncevic-Orlic Z, Kovac Z, Polasek O, Soldo-Juresa D. Vitamin D status, dependence on age, and seasonal variations in the concentration of vitamin D in Croatian postmenopausal women initially screened for osteoporosis. Clin Rheumatol. 2010;29:861-7

40. Maddah M, Sharami SH, Neyestani TR. Vitamin D insufficiency among postmenopausal women in urban and rural areas in Guilan, Northern Iran. Jutr Elder. 2009;28(4):386-93. 
41. Garnero P, Munoz F, Sornay-Rendu E, Delmas PD. Associations of vitamin $D$ status with bone mineral density, bone turnover, bone loss and fracture risk in healthy postmenopausal women. The OFELY study. Bone. 2007;40(3):716-22

42. Casado-Diaz A, Cuenca-Acevedo R, Navarro-Valverde C, et al. Vitamin D status and the $C d x-2$ polymorphism of the vitamin $D$ receptor gene are determining factors of bone mineral density in young healthy postmenopausal women. J Steroid Biochem Mol Biol. 2013;136:187-9.

43. Hussein KS, Al Kadi HA, Lanham-New SA, Ardawi MSM. Prevalence of vitamin D deficiency in pre-and postmenopausal Saudi women - A cross sectional study. Bone. 2012;50(1):138.

44. Baro F. Vitamin D deficiency in Spanish postmenopausal women. Osteoporos Int. 2011;22(1):405

45. Bobinac D, Stareeviae G, Cvijanoviae O, Fuzinac A, Arbanas |, Zorieiae S. Serum vitamin $D$ level and bone mineral density in premenopausal and postmenopausal women in Croatia. Bone. 2009;44(1):65-6.

46. Poiana $C$, Carsote M, Neacsu E, et al. Vitamin D levels and bone mineral density in 174 postmenopausal women. Bone. 2009;44(2):398. 